JOLL 3 (2) (2020)

Journal Of Lifelong Learning

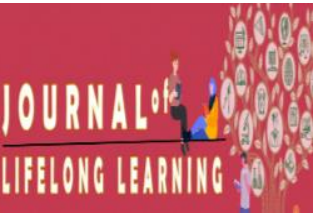

\title{
ANALISIS KESIAPAN PKBM DALAM MENGHADAPI AKREDITASI BERBASIS SISPENA 2.0 DI KABUPATEN REJANG LEBONG
}

\section{Rola Pebrianti ${ }^{1}$, Wahirudin $^{2}$, Bayu Pradikto ${ }^{3}$}

${ }^{1}$ Rola Pebrianti, Universitas Bengkulu, Indonesia, rolafeb@ gmail.com

${ }^{2}$ Wahirudin, Universitas Bengkulu, Indonesia, wahiruddinwadin@gmail.com

${ }^{3}$ Bayu Pradikto, Universitas Bengkulu, Indonesia, bayupradikto@unib.ac.id

\begin{abstract}
The purpose of this research is to measure the percentage of management readiness of PKBM in following accreditation. This research was a quantitative descriptive study using a questionnaire as the research instrument. The sample in this study was 8 respondents who were PKBM managers in Rejang Lebong Regency. The finding obtained from the results of the PKBM readiness in registering institutions in SISPENA showed a percentage of $84.28571 \%$ so that it was included in the category of very ready to register their institutions at SISPENA. For the readiness of 8 standard documents, the research results obtained show a percentage of $71.25673 \%$ so that it was included in the quite ready category. For performance readiness/ implementation of activities, the results of the study showed a percentage of $62.32039 \%$ so that it was included in the category of not ready. Based on research findings, it was known that the obstacles in preparing the accreditation process were cost and human resources. The conclusion from this study was that PKBM managers in Rejang Lebong Regency were very prepared to register their institutions in SISPENA because all PKBM already have an NPSN as the main requirements for admission to SISPENA. In addition, it was also known that PKBM managers are quite prepared in preparing 8 standard documents because on average PKBM managers already have 8 standard documents. The manager of PKBM was not ready to prepare the performance/implementation of activities because the data found was not in accordance with 8 standard documents.
\end{abstract}

Keywords: Accreditation, PKBM

(C2020 DeptofNonformalEducationUNIB ISSN : 2715-9809

\section{Addresscorrespondence:}

Jl.W.R.Supratman,KandangLimun,MuaraBangkaHulu, KotaBengkulu,Bengkulu38371 


\section{PENDAHULUAN}

Sistem Pendidikan Nasional menurut Undang-Undang RI No 20 Tahun 2003 adalah keseluruhan komponen pendidikan yang saling terkait secara terpadu untuk mencapai tujuan Pendidikan Nasional. Pada setiap Kabupaten dan provinsi di Indonesia menyelenggarakan pendidikan nasional yang mengacu pada sistem Pendidikan Nasional. Sistem Pedidikan Nasional diatur dalam Undang Undang SISDIKNAS Nomor 20 tahun 2003. Selanjutnya, dijelaskan Dalam Undang-Undang SISDIKNAS Nomor 20 tahun 2003 pendidikan adalah : Sebagai usaha sadar dan terencana untuk mewujudkan suasana belajar dan proses pembelajaran sedemikian rupa supaya peserta didik dapat mengembangkan potensi dirinya secara aktif supaya memiliki pengendalian diri, kecerdasan, keterampilan dalam bermasyarakat, kekuatan spiritual keagamaan, kepribadian serta akhlak mulia.

Dalam Undang-Undang Nomor 20 Tahun 2003 pasal 13 ayat 1 di kemukakan bahwa, "Jalur pendidikan terdiri atas pendidikan formal, nonformal dan informal yang dapat saling melengkapi dan memperkaya". Selanjutnya, Pasal 1 Ayat12 Undang-Undang SISDIKNAS Nomor. 20 Tahun 2003 dikemukakan bahwa Pendidikan Non Formal adalah "Jalur pendidikan di luar pendidikan formal yang dapat dilaksanakan secara terstruktur dan berjenjang". Jalur Pendidikan Non Formal diselenggarakan bagi warga masyarakat yang memerlukan layanan pendidikan yang berfungsi sebagai pengganti, penambah dan/atau pelengkap pendidikan formal dalam rangka mendukung pendidikan sepanjang hayat.

Ada beberapa satuan PNF yang menjadi bidang garapan PNF yang di kelompokkan menjadi PAUD, LKP, dan PKBM, SPNFSKB, BP PAUD DIKMAS, di dalam Undang-Undang SISDIKNAS
Nomor 20 Tahun 2003 program layanan PNF itu dirincikan sebagai berikut: "Pendidikan Kecakapan Hidup, Pendidikan Anak Usia Dini, Pendidikan Kepemudaan, Pendidikan Pemberdayaan Perempuan, Pendidikan Keaksaraan, Pendidikan Keterampilan dan Pelatihan Kerja, Pendidikan Kesetaraan, dan pendidikan lain yang ditujukan untuk mengembangkan kemampuan peserta didik".

PKBM. Pusat Kegiatan Belajar Masyarakat (PKBM) secara khusus disebut di dalam Undang-Undang SISDIKNAS Nomor 20 Tahun 2003 sebagai satuan penyelenggaraan pendidikan non formal. Program pada PKBM ini meliputi program pendidikan kesetaraan (Paket A, Paket B, dan Paket C), pendiddikan keaksaraan fungsional (keaksaraan dasar dan keaksaraan usaha mandiri).

PKBM akan diizinkan melaksanakan ujian nasional untuk Program Pendidikan Kesetaraan saat telah memiliki akreditasi. Untuk mendapatkan akreditasi ini PKBM harus lolos penilaian dari BAN PAUD DAN PNF. Untuk melihat kelayakan PKBM, BAN PAUD DAN PNF menggunakan instrumen akreditasi yang mengacu pada Standar Nasional Pendidikan (SNP) sebagaimana ditetapkan melalui Peraturan Pemerintah Republik Indonesia Nomor 32 Tahun 2013 tentang Perubahan atas Peraturan Pemerintah Republik Indonesia Nomor 19 Tahun 2005, yang mencakup 8 (delapan) standar, yaitu 1) Standar Kompetensi Lulusan, 2) Standar Isi, 3) Standar Proses, 4) Standar Pendidik dan Tenaga Kependidikan, 5) Standar Sarana dan Prasarana, 6) Standar Pengelolaan, 7) Standar Pembiayaan dan 8) Standar Penilaian Pendidikan.

Menurut referensi data pendidikan kemdikbud jumlah PKBM di Provinsi Bengkulu pada tahun 2019 terdapat sebanyak 158 PKBM yang tersebar di 10 Kabupaten. Jumlah PKBM di Kab. Rejang 
Lebong sendiri menurut data rekapitulasi lembaga DIKMAS Pendidikan Non Formal di Website Kemedikbud tahun 2019 terdapat 8 PKBM yaitu PKBM Wijaya Kusuma, PKBM Bima Sejahtera, PKBM Sekar Wangi, PKBM Mitra Jaya, PKBM Ratu Rafa, PKBM Mata Hati, PKBM Bina Mandiri, dan PKBM ESMAT. Dari ke delapan` PKBM tersebut belum ada satupun PKBM yang terakreditasi di tahun 2019 ( data pertanggal 1 Desember 2019).

Tujuan akreditasi adalah untuk menentukan kelayakan program dan satuan pada jalur pendidikan nonformal pada setiap jenjang dan jenis pendidikan. Akreditasi merupakan salah satu upaya pemerintahan untuk meningkatkan mutu dan layanan, maka satuan penyelenggara pendidikan perlu dilakukan akreditasi.

Untuk mengetahui seberapa persen kesiapan pengelola PKBM di Kabupaten Rejang Lebong dalam mempersiapkan akreditasi, maka penulis tertarik melakukan penelitian dengan judul "Analisis Kesiapan Pkbm Dalam Menghadapi Akreditasi Berbasis Sispena 2.0 Di Kabupaten Rejang Lebong

\section{METODE}

Lokasi penelitian dilakukan di delapan PKBM di Kabupaten Rejang Lebong yaitu PKBM Wijaya Kusuma, PKBM Bima Sejahtera, PKBM Sekar Wangi, PKBM Mitra Jaya, PKBM Ratu Rafa, PKBM Mata Hati, PKBM Bina Mandiri, dan PKBM E Smat.

Peneliti menggunakan metode deskriptif kuantitatif untuk mencapai tujuan penelitian. Menurut Sugiyono (2015:8), metode penelitian kuantitatif merupakan : Metode penelitian yang berlandaskan pada filsafat positivisme, digunakan untuk meneliti pada populasi atau sampel tertentu, teknik pengambilan sampel pada umumnya dilakukan secara random, pengumpulan data menggunakan instrumen penelitian, analisis data bersifat kuantitatif/statistik dengan tujuan untuk menguji hipotesis yang telah ditetapkan.

Dalam penelitian ini, peneliti menggunakan Kuesioner(angket) untuk mencapai tujuan penelitian nomor 1 sampai nomor 3. Partisipan dalam penelitian ini adalah pengelola dari 8 PKBM di Kabupaten Rejang Lebong yaitu PKBM Wijaya Kusuma, PKBM Bima Sejahtera, PKBM Sekar Wangi, PKBM Mitra Jaya, PKBM Ratu Rafa, PKBM Mata Hati, PKBM Bina Mandiri, dan PKBM E Smat.

Populasi pada penelitian ini ada 8 PKBM. Menurut Sugiyono (2013:119) populasi adalah wilayah generalisasi yang terdiri atas : obyek/subyek yang mempunyai kualitas dan berkarakteristik tertentu yang ditetapkan oleh peneliti untuk dipelajari kemudian ditarik kesimpulannya. Sedangkan sampel untuk penelitan ini ada 8 PKBM sama dengan jumlah populasi karena teknik pengambilan sampel yang digunakan dalam penelitian ini adalah total sampling. Menurut Sugiyono (2011) Total sampling adalah teknik pengambilan sampel dimana jumlah populasi sama dengan jumlah sampel. Total sampling diakukan jika jumlah populasi kurang dari 100 .

Teknik pengumpulan data yang digunakan dalam penelitian ini adalah angket. Instrumen yang digunakan pada peneltian ini mengacu pada intrumen evaluasi diri di dalam SISPENA dan instrumen penilaian dari BAN PAUD dan PNF yang telah diuji oleh para ahli yaitu Drs. Rufran Zulkarnain, M.Pd sebagai akdemisi, Dian Eka Gustini, M.Pd.sebagai perwakilan dari BAN PAUD dan PNF Bengkulu, dan Peavey Marisha S.PdI sebagai asesor BAN PAUD dan PNF Bengkulu.

Analisis data yang digunakan adalah analisis deskriptif dan interpretasi data. 
Pada analisis deskriptif peneliti akan mendeskripsikan data yang didapatkan dari hasil penelitian dengan bentuk uraian kalimat. Sedangkan pada interpetasi data peneliti akan menyajikan hasil penelitian dengan dengan angka presentase kesiapan PKBM beserta uraian deskriptif berdasarkan presentase yang didapat dari hasil penelitian. Pada interpretasi data peneliti akan menyajikan hasil penelitian dengan dengan angka presentase kesiapan PKBM beserta uraian deskriptif berdasarkan presentase yang didapat dari hasil penelitian. Data dari angket dalam penelitian ini merupakan data kuantitatif yang akan dianalisis secara deskriptif persentase dengan langkahlangkah menurut Riduan (2004:71-95) sebagai berikut:

a. Menghitung nilai responden dan masing-masing aspek atau sub variabel.

b. Merekap nilai.

c. Menghitung nilai rata-rata.

d. Menghitung persentase dengan rumus: $D P=\frac{n}{N} \times 100$

Untuk mengetahui tingkat kriteria tersebut, selanjutnya skor yang diperoleh (dalam \%) dengan analisis deskriptif persentase dikonsultasikan dengan tabel kriteria. Untuk mengetahui tingkat kriteria tersebut, selanjutnya skor yang diperoleh (dalam \%) dengan analisis deskriptif persentase dikonsultasikan dengan tabel kriteria. Cara menetukan presentase tertinggi dan terendah terlebih dahulu menggunakan rumus sebagai berikut :

1) Menentukan angka persentase tertinggi

Skor tertinggi / Skor tertinggi $\mathrm{x}$ $100 \%$

$$
\frac{4}{4} \times 100=100 \% \%
$$

2) Menentukan angka persentase terendah

Skor minimal / Skor maksimal $\mathrm{x}$ $100 \%$

$$
\frac{1}{4} \times 100=25 \%
$$

Setelah memperoleh presentase tertinggi dan terendah langkah selanjutnya adalah menentukan interval kelas dengan rumus interval kelas dalam Sudjana, 2002:47.

interval kelas $=$
skor tertinggi-skor terendah
kelas yang dikehendaki

Sehingga interval kelas pada penelitian ini adalah :

$$
18,75=\frac{100-25}{4}
$$

\begin{tabular}{|c|c|}
\hline Presentase & Kriteria \\
\hline $25-43,75 \%$ & Tidak siap \\
\hline $43,75-62,50 \%$ & Kurang siap \\
\hline $62,51-81,75 \%$ & Cukup siap \\
\hline $81,76-100 \%$ & Sangat siap \\
\hline
\end{tabular}

\section{HASIL DAN PEMBAHASAN}

Berdasarkan hasil penelitian di Kab. Rejang Lebong diketahui bahwa jumlah PKBM yang aktif beroperasi di Kabupaten Rejang Lebong adalah 7 PKBM, diketahui bahwa PKBM E-SMAT CURUP tidak aktif beroperasi lagi.

\section{a. Kesiapan pengelola dalam} mendaftarkan lembaga di SISPENA

Nilai rata-rata presentase kesiapan pengelola PKBM di Kab. Rejang Lebong dalam mendaftarkan lembaga di sispena adalah sebesar 84,285\%. Dalam skala yang digunakan dalam penelitian ini $84,285 \%$ masuk kedalam kategori sangat siap. Hal ini dikarenakan PKBM telah memiliki dokumen yang diperlukan untuk pendaftaran lembaga pada sispena, seperti pada poin 2 yaitu surat permohonan yang akan diunggah, pada poin 3 yaitu kurikulum yang akan diunggah pengelola PKBM sudah memiliki kurikulum yang akan diunggah pada saat proses pendaftaran di web SISPENA, pada poin 4 yaitu mengunggah legalitas lembaga ketujuh 
PKBM telah memiliki dokumen legalitas lembaga mereka masingmasing. Karena kelengkapan dokumen telah dimiliki oleh pengelola PKBM di Kabupaten Rejang Lebong, maka presentase yang didapatkan dari hasil penelitian sebesar angka 84,285\% menunjukkan bahwa pengelola PKBM di Kabupaten Rejang Lebong sudah sangat siap dalam mendaftarkan lembaganya di SISPENA.

Menurut data dari BAN PAUD PNF tahun 2019 proses pendaftaran lembaga di SISPENA hanya dapat dilakukan oleh PKBM yang sudah mendapatkan NPSN. Hal inilah yang membuat hasil penelitian tentang kesiapan PKBM dalam mendaftarkan lembaga dikategorkan sangat siap. Berdasarkan hasil penelitian seluruh PKBM di Kabupaten Rejang Lebong diketahui sudah memiliki NPSN sebagai syarat utama untuk pendaftaran lembaga di SISPENA.

Menurut Slameto (2010:113), kesiapan adalah keseluruhan kondisi seseorang yang membuatnya siap untuk memberikan respon atau jawaban dalam cara tertentu terhadap sebuah situasi. Penyesuaian kondisi pada suatu saat akan berpengaruh atau kecenderungan untuk memberi respon. Pada penelitian ini kesiapan yang dimaksud oleh peneliti adalah kesiapan pengelola PKBM dalam mendaftarkan lembaga di SISPENA dalam rangka menghadapi akreditasi.

\section{b. Kesiapan Pengelola PKBM dalam Mempersiapkan Dokumen 8 Standar}

Presentase nilai kesiapan pengelola PKBM di Kabupaten Rejang Lebong dalam mempersiapkan dokumen standar kompetensi lulusan menunjukkan angka 69,64285\% yang berarti pengelola PKBM sudah cukup siap dalam mempersiapkan dokumen standar kompetensi lulusan. Pada standar ini, PKBM yang mendapatkan nilai terendah adalah PKBM Mata Hati dengan nilai 43,75\%. PKBM Mata hati sendiri mendapatkar skor 1 (tidak siap) pada dokumen rumusan standar kompetensi dasar dari setiap program PKBM dan rumusan indikator kelulusan setiap program yang diselenggarakan PKBM. Pada standar kompetensi lulusan ini tidak ada 4 PKBM mendapatkan nilai diatas $81,75 \%$ yang menunjukkan bahwa PKBM di Kab. Rejang Lebong belum ada yang sangat siap dalam mempersiapkan dokumen standar kompetensi ini.

Setelah di ambil nilai rata-rata kesiapan pengelola PKBM dalam mempersiapkan dokumen standar kompetensi lulusan menunjukkan nilai $\mathbf{6 9 , 6 4 2 8 5 \%}$ yang berarti pengelola cukup siap dalam mempersiapkan dokumen standar kompetensi lulusan.

Presentase nilai kesiapan pengelola PKBM di Kabupaten Rejang Lebong dalam mempersiapkan dokumen standar isi menunjukkan angka $\mathbf{7 4 . 4 0 1 \%}$ yang berarti pengelola PKBM sudah cukup siap dalam mempersiapkan dokumen standar isi. Pada standar ini PKBM yang mendapat skor terendah adalah PKBM Mata Hati sebesar 58,3\% lalu diikuti PKBM Bina Mandiri sebesar 66,67\% dan Mitra Jaya sebesar 66,67\%, Dokumen yang paling banyak mendapat skor 2 (kurang siap) adalah dokumen analisis kebutuhan pembelajaran peserta didik di setiap program PKBM.

Dokumen yang perlu dipersiapkan didalam standar isi sendiri merupakan dokumen silabus, dokumen analisis kebutuhan belajar, dokumen laporan kegiatan, dokumen kurikulum, dokumen kalender pendidikan dan dokumen sosialisasi kalender pendidikan.

Setelah di ambil nilai rata-rata kesiapan pengelola PKBM dalam 
mempersiapkan dokumen standar isi menunjukkan nilai $\mathbf{7 4 . 4 0 1 \%}$ yang berarti pengelola cukup siap dalam mempersiapkan dokumen standar isi.

Presentase nilai kesiapan pengelola PKBM di Kabupaten Rejang Lebong dalam mempersiapkan dokumen standar proses menunjukkan angka $\mathbf{7 7 , 8 5 \%}$ yang berarti pengelola PKBM sudah cukup siap dalam mempersiapkan dokumen standar proses. Pada standar ini ada tiga PKBM yang mendapatkan nilai presentase diatas $81,75 \%$ yaitu PKBM Wijaya Kusuma, Bina Sejahtera, dan Ratu Rafa yang menunjukkan bahwa PKBM sangat siap dalam mempersiapkan dokumen standar proses. Dokumen yang diperlukan dalam standar proses adalah dokumen rencana program pembelajaran,kontrak belajar,daftar kehadiran peserta didik,daftar kehadiran pendidik dan tenaga kependidikan.

Setelah di ambil nilai rata-rata kesiapan pengelola PKBM dalam mempersiapkan dokumen standar proses menunjukkan nilai $\mathbf{7 7 , 8 5 \%}$ yang berarti pengelola cukup siap dalam mempersiapkan dokumen standar proses.

Presentase nilai kesiapan pengelola PKBM di Kabupaten Rejang Lebong dalam mempersiapkan dokumen standar pendidik dan tenaga kependidikan menunjukkan angka $\mathbf{7 6 , 1 8 8 5 7 \%}$ yang berarti pengelola PKBM sudah cukup siap dalam mempersiapkan dokumen standar pendidik dan tenaga kependidikan. Pada standar ini ada 2 PKBM yang mendapat nilai terendah yaitu PKBM Sekar wangi dan PKBM Mata Hati yaitu sebesar 50\%. PKBM Sekar wangi dan PKBM Mata Hati mendapat skor 2 (kurang siap) pada seluruh poin didalam standar pendidik dan tenaga kependidikan, yaitu dokumen jumlah dan kualifikasi akademik pendidik, dokumen jumlah dan kualifikasi tenaga kependidikan dan dokumen pengalaman kerja pendidik dan tenaga kependidikan.

Setelah di ambil nilai rata-rata kesiapan pengelola PKBM dalam mempersiapkan dokumen standar pendidik dan tenaga kependidikan menunjukkan nilai $\mathbf{7 6 , 1 8 8 5 7 \%}$ yang berarti pengelola cukup siap dalam mempersiapkan dokumen standar pendidik dan tenaga kependidikan.

Presentase nilai kesiapan pengelola PKBM di Kabupaten Rejang Lebong dalam mempersiapkan dokumen standar sarana dan prasarana menunjukkan angka $\mathbf{6 3 . 5 7 1 4 2 \%}$ yang berarti pengelola PKBM sudah cukup siap dalam mempersiapkan dokumen standar sarana dan prasarana. Pada standar ini tidak ada PKBM yang mendapat nilai presentase diatas $81,75 \%$. Dokumen yang perlu disiapkan dalam standar ini adalah dokumen jenis dan jumlah peralatan pembelajaran, dokumen ketersediaan bahan bacaan, dokumen penggunaan media pembelajaran secara online, dokumen keberadaan sarana prasarana ruangan PKBM, dan dokumen kepemilikan atau penggunaan lahan atau gedung.

Setelah di ambil nilai rata-rata kesiapan pengelola PKBM dalam mempersiapkan dokumen standar pendidik dan tenaga kependidikan menunjukkan nilai $\mathbf{6 3 . 5 7 1 4 2 \%}$ yang berarti pengelola cukup siap dalam mempersiapkan dokumen standar sarana dan prasarana.

Presentase nilai kesiapan pengelola PKBM di Kabupaten Rejang Lebong dalam mempersiapkan dokumen standar pengelolaan menunjukkan angka $\mathbf{7 5 . 3 5 7 1 4 \%}$ yang berarti pengelola PKBM sudah cukup siap dalam mempersiapkan dokumen standar pengelolaan. Dalam standar ini ada 3 
PKBM yang mendapatkan nilai presentase diatas $81,75 \%$ untuk nilai terendah diperoleh PKBM Sekar Wangi sendiri dan Mata Hati. PKBM Sekar Wangi sendiri mendapat skor 2(kurang siap) pada 8 dari 10 poin pada standar ini, sedangkan PKBM Mata Hati mendapat skor 1(tidak siap) pada 2 dari 10 poin pada standar ini.

Setelah di ambil nilai rata-rata kesiapan pengelola PKBM dalam mempersiapkan dokumen standar pendidik dan tenaga kependidikan menunjukkan nilai $\mathbf{7 5 . 3 5 7 1 4 \%}$ yang berarti pengelola cukup siap dalam mempersiapkan dokumen standar pengelolaan.

Presentase nilai kesiapan pengelola PKBM di Kabupaten Rejang Lebong dalam mempersiapkan dokumen standar pembiayaan menunjukkan angka $\mathbf{7 1 . 4 2 8 5 7 \%}$ yang berarti pengelola PKBM sudah cukup siap dalam mempersiapkan dokumen standar pembiayaan. Pada standar ini ada 2 PKBM yang mendapat nilai presentase diatas $81,75 \%$ yaitu PKBM Bina Sejahter dan Ratu Rafa, sedangkan nilai terendah diperoleh PKBM Sekar wangi sebesar 50\% dan PKBM Mata Hati sebesar 25\%. PKBM Mata Hati sendiri mendapatkan skor 2 (tidak siap) pada 2 poin dalam standar pengelolaan yaitu dokumen pedoman dan instrumen pengawasan,pemantauan dan evaluasi serta dokumen notulensi rapat rutin pembinaan PKBM. PKBM Sekar wangi sendiri mendapat skor 2(kurang siap) pada 8 poin dari 10 poin dalam standar pembiayaan.

Presentase nilai kesiapan pengelola PKBM di Kabupaten Rejang Lebong dalam mempersiapkan dokumen standar penilaian pendidikan menunjukkan angka $\begin{array}{lrrr}\mathbf{6 1 . 6 0 7 1 4 \%} & \text { yang } & \text { berarti } & \text { pengelola } \\ \text { PKBM } & \text { kurang } & \text { siap } & \text { dalam }\end{array}$ mempersiapkan dokumen standar penilaian pendidikan. Pada standar ini tidak ada satu PKBM yang mendapatkan nilai diatas $81,75 \%$.

Dokumen yang perlu disiapkan dalam standar ini antara lain dokumen panduan/ pedoman penilaian untuk setiap program PKBM, dokumen intrumen penilaian setiap program PKBM, dokumen data peserta didik yang terdaftar dan selesai mengikuti pembelajaran/lulus ujian nasional pendidikan kesetaraan atau uji kompetensi oleh LSP/LSK dan dokumen penghargaan/prestasi yang diperoleh peserta didik,pendidik dan tenaga kependidikan PKBM.

Keseluruhan nilai presentase standar 1 sampai standar 8 yang didapatkan yaitu 71,25\%. Dari dalam 8 standar ada tidak ada satu standar yang mendapat nilai presentase diatas $81,75 \%$ yang menunjukkan tidak ada pengelola PKBM sangat siap dalam mempersiapkan dokumen. Dalam skala yang digunakan dalam penelitian ini $\mathbf{7 1 , 2 5 \%}$ masuk kedalam kategori cukup siap. Hal ini menunjukkan bahwa PKBM di Kabupaten Rejang Lebong cukup siap untuk mempersiapkan Dokumen 8 standar.

Kesiapan pengelola PKBM di Kab. Rejang Lebong masuk kedalam kategori cukup siap. Analisa peneliti di lapangan menunjukkan bahwa beberapa faktor yang menjadi kendala dalam pemenuhan 8 standar antara lain adalah biaya dan sumber daya manusia (SDM).

Menurut Dewi (2017) dalam penelitiannya menyatakan bahwa faktor yang menjadi kendala lembaga dalam memenuhi delapan standar pada Pelaksanaan akreditasi adalah biaya, waktu dan sumber daya manusia (SDM). Peneliti memiliki pendapat yang sama terhadap hasil penelitian terdahulu terkait 
faktor yang menjadi kendala lembaga dalam hal ini PKBM dalam memenuhi 8 standar adalah biaya, waktu dan sumber daya manusia (SDM).

Dalam hasil penelitian mengenai kesiapan pengelola dalam mempersiapkan dokumen 8 standar PKBM di Kabupaten Rejang Lebong mendapatkan nilai presentase dibawah $75 \%$ yaitu pada standar kompetensi lulusan, standar isi, standar sarana prasarana, standar pembiayaan, dan standar penilaian pendidikan. Hal ini disebabkan oleh tidak dimilikinya SDM yang kompeten untuk membuat dan menyusun dokumen-dokumen pada standar kompetensi dan standar isi.Selain itu biaya juga menjadi kendala dalam pemenuhan dokumen standar sarana prasarana dan standar pembiayaan, hasil penelitian pada PKBM di Kabupaten Rejang Lebong menunjukkan bahwa karena keterbatasan biaya PKBM belum bisa memenuhi standar tersebut. Karena keterbatasan biaya yang ada pengelola PKBM tidak dapat menyediakan sarana dan prasarana yang cukup serta membayar SDM yang kompeten untuk pengelolan lembaga. Seperti pada PKBM Mata Hati sendiri belum mendapatkan bantuan biaya dari pemerintah dan hanya mengandalkan biaya dari warga belajar sehingga membuat pembiayaan operasional PKBM cukup sulit.

\section{c. Kesiapan Pengelola PKBM dalam Mempersiapkan Unjuk kerja/pelaksanaan kegiatan}

Presentase nilai kesiapan pengelola

PKBM di Kabupaten Rejang Lebong dalam mempersiapkan unjuk kerja/Pelaksanaan kegiatan standar kompetensi lulusan menunjukkan angka $\mathbf{5 8 . 3 3 4 2 8 \%}$ yang berarti pengelola PKBM kurang siap dalam mempersiapkan unjuk
kerja/Pelaksanaan standar kompetensi lulusan. Pada standar ini tidak ada PKBM yang mendapat nilai presentase diatas $81,75 \%$.

Data yang dimuat dalam standar kompetensi lulusan ini adalah data tentang lulusan dan pemanfaatan belajar, data tentang kebermanfaatan dan data tentang rata-rata masa tunggu lulusan. Data tentang rata-rata masa tunggu lulusan adalah data yang paling banyak mendapat skor 1 (tidak siap) pada standar ini.

Presentase nilai kesiapan pengelola PKBM di Kabupaten Rejang Lebong dalam mempersiapkanunjuk kerja/ Pelaksanaan kegiatan standar isi menunjukkan angka $60 \%$ yang berarti pengelola PKBM kurang siap dalam mempersiapkan unjuk kerja/Pelaksanaan standar isi. Pada standar ini tidak ada PKBM yang mendapatkan nilai presentase diatas $81,75 \%$.

Pada standar isi data yang dimuat adalah data tentang kegiatan pengembangan kurikulum berbasis kebutuhan masyarakat, data tentang materi yang memuat kearifan lokal, data tentang pemanfaatan dan penggunaan bahan ajar berbasis potensi masyarakat, data tentang pemanfaatan alam dan lingkungan sosial dan data tentang kontribusi masyarakat terhadap kegiatan pembelajaran. Data tentang materi yang memuat kearifan local adalah data yang paling banyak mendapat skor 2 (kurang siap) pada standar ini.

Presentase nilai kesiapan pengelola PKBM di Kabupaten Rejang Lebong dalam mempersiapkan unjuk kerja/Pelaksanaan kegiatan standar proses menunjukkan angka 62.21342\% yang berarti pengelola PKBM kurang siap dalam mempersiapkan unjuk kerja/Pelaksanaan standar proses. Pada 
standar ini ada satu PKBM yang mendapat nilai presentase diatas $81,75 \%$ yaitu PKBM Ratu rafa.

Dokumen yang dimuat dalam standar proses adalah data kesesuaian kontrak belajar,data tentang penerapan kurikulum, data tentang berbagai jenis proses pembelajaran, data tentang aktivitas pembelajaran dengan memanfaatkan Sistem Informasi Manajemen(SIM) berbasis internet, data tentang aktivitas pembelajaran yang partisipatif dan data tentang aktivitas bimbingan dan pengayaan peserta didik. Data yang paling banyak mendapat skor 1(tidak siap) dan 2(kurang siap) adalah data tentang aktivitas pembelajaran yang partisipatif.

Presentase nilai kesiapan pengelola PKBM di Kabupaten Rejang Lebong dalam mempersiapkan unjuk kerja/Pelaksanaan kegiatan standar pendidik dan tenaga kependidikan menunjukkan angka 65.09685\% yang berarti pengelola PKBM sudah cukup siap dalam mempersiapkan unjuk kerja/Pelaksanaan standar pendidik dan tenaga kependidikan. Pada standar ini nilai presentase terendah diperoleh oleh PKBM Mata Hati yaitu sebesar $25 \%$.

Data yang dimuat dalam standar ini adalah data mekanisme rekrutmen pendidik, data mekanisme rekrutmen tenaga kependidikan, data upaya yang dilakukan pengelola dalam meningkatkan kualifikasi dan kompetensi pendidik dan data upaya yang dilakukan pengelola dalam meningkatkan kualifikasi dan kompetensi tenaga kependidikan.

Presentase nilai kesiapan pengelola PKBM di Kabupaten Rejang Lebong dalam mempersiapkan unjuk kerja/Pelaksanaan kegiatan standar sarana dan prasarana menunjukkan angka $\mathbf{6 5 . 3 0 4 2 8 \%}$ yang berarti pengelola PKBM sudah cukup siap dalam mempersiapkan unjuk kerja/Pelaksanaan standar sarana dan prasarana. Dalam standar ini hanya ada satu PKBM yang mendapatkan nilai presentase diatas $81,75 \%$ yaitu PKBM Bina Sejahtera. Data yang paling banyak mendapat skor 1(tidak siap) adalah data tentang perawatan dan pemeliharaan area ruang kantor, perpustakaan, ruang baca, ruang tamu, toilet halaman dan parkir.

Presentase nilai kesiapan pengelola PKBM di Kabupaten Rejang Lebong dalam mempersiapkan unjuk kerja/Pelaksanaan kegiatan standar pengelolaan menunjukkan angka $\mathbf{5 7 . 8 5 7 1 4 \%}$ yang berarti pengelola PKBM kurang siap dalam mempersiapkan unjuk kerja/Pelaksanaan standar pengelolaan. Dalam standar ini hanya ada satu PKBM yang mendapat nilai presentase diatas $81,75 \%$ yaitu PKBM Sekar Wangi yaitu sebesar $85 \%$ sedangkan, nilai presentase terendah didapatkan PKBM Mata Hati yaitu sebesar 25\%.

Data yang dimuat dalam standar ini adalah data tentang kerjasama PKBM dengan mitra yang relevan, data kegiatan unit produksi atau usaha, data tentang program unggulan, data tentang cara pengelola melakukan pengawasan internal untuk menjamin mutu program, data tentang cara pengelola melakukan pengawasan eksternal untuk menjamin mutu program. Data yang paling banyak mendapat skor 1(tidak siap) adalah data tentang kegiatan unit produksi atau usaha yang dilakukan

Presentase nilai kesiapan pengelola PKBM di Kabupaten Rejang Lebong dalam mempersiapkan unjuk kerja/Pelaksanaan kegiatan standar pembiayaan menunjukkan angka 65.47\% yang berarti pengelola PKBM 
sudah cukup siap dalam mempersiapkan unjuk kerja/Pelaksanaan standar pembiayaan. Pada standar ini nilai presentase terendah didapatkan PKBM Mata Hati yaitu sebesar 25\% .

Data yang dimuat dalam standar ini adalah data tentang sumber pembiayaan penyelenggaraan program, data tentang sumber pembiayaan bagi peserta didik dari pemerintah, swasta, beasiswa atau pihak lainnya, dan data tentang tata kelola keuangan. Data yang paling banyak mendapat skor 1(tidak siap) adalah data tentang data tentang sumber pembiayaan bagi peserta didik dari pemerintah, swasta, beasiswa atau pihak lainnya.

Presentase nilai kesiapan pengelola PKBM di Kabupaten Rejang Lebong dalam mempersiapkan unjuk kerja/Pelaksanaan kegiatan standar penilaian pendidikan menunjukkan angka $\mathbf{6 4 . 2 8 1 4 2 \%}$ yang berarti pengelola PKBM sudah cukup siap dalam mempersiapkan unjuk kerja/Pelaksanaan standar penilaian pendidikan. Pada standar ini skor paling rendah didapatkan oleh PKBM Mata Hati yaitu sebesar $35,71 \%$. Data yang paling banyak mendapat skor 1(tidak siap) adalah data tentang prestasi, kejuaraan, perlombaan dan apresiasi yang dicapai peserta didik PKBM.

Keseluruhan nilai presentase dari standar 1 sampai standar 8 yang didapatkan yaitu 62.32039\%. Dari 8 standar untuk mempersiapkan unjuk kerja/ Pelaksanaan kegiatan tidak ada satu standar pun yang mendapat nilai presentase diatas $81,75 \%$. Dalam skala yang digunakan dalam penelitian ini 62.32039\%. masuk kedalam kategori kurang siap. Hal ini menunjukkan bahwa PKBM di Kabupaten Rejang Lebong kurang siap untuk mempersiapkan unjuk kerja/Pelaksanaan kegiatan.

Kesiapan pengelola PKBM di Kab. Rejang Lebong masuk kedalam kategori kurang siap. Analisa peneliti di lapangan menunjukkan bahwa beberapa faktor yang menjadi kendala PKBM pada saat unjuk kerja/Pelaksanaan kegiatan adalah tidak ada catatan atau rekapan yang lengkap mengenai alumni warga belajar, dan data-data lain yang ditemukan kurang sesuai dengan dokumen.

Menurut asesor BAN PAUD dan PNF beberapa hal yang menjadi kendala dalam kegiatan unjuk kerja/Pelaksanaan kegiatan yang dimuat dalam catatan penilaian adalah tidak dapat menghadirkan data keberlanjutan lulusan, tidak dapat menghadirkan proses belajar yang aktif, RPP masih mengacu pada sekolah formal, kontrak belajar masih copy paste dari contoh di sispena, tidak mempunyai usaha mandiri, tidak punya sop keuangan, dan pengelolaan keuangan internal yang tidak tertib.

Dalam hasil penelitian mengenai kesiapan pengelola PKBM di Kabupaten Rejang Lebong dalam mempersiapkan unjuk kerja/Pelaksanaan kegiatan tidak ada satu standar pun yang mendapat nilai presentase diatas $75 \%$. Hal ini dikarenakan pengelola/SDM kurang kompeten dalam mempersiapkan unjuk kerja/ Pelaksanaan kegiatan. Pengelola harus memiliki SDM yang berkompeten untuk menyiapkan sumber data sebelum proses visitasi akreditasi dimulai. Pada unjuk kerja/Pelaksanaan kegiatan dibutuhkan data-data yang dimintai langsung oleh asesor kepada berbagai pihak yang terlibat dalam proses pembelajaran di sebuah PKBM. Seperti 
data untuk standar kompetensi lulusan diambil dari keterangan alumni PKBM.

\section{KESIMPULAN}

Berdasarkan hasil penelitian tentang kesiapan pengelola PKBM dalam mempersiapkan akreditasi di Kabupaten Rejang Lebong, maka dapat ditarik kesimpulan sebagai berikut bahwa Kesiapan pengelola dalam mendaftarkan lembaga di SISPENA adalah sebesar 84,28571\% sehingga masuk dalam kategori sangat siap karena seluruh PKBM di Rejang Lebong sudah memiliki NPSN sebagai syarat utama masuk ke SISPENA.

Kesiapan pengelola PKBM di Kabupaten Rejang Lebong dalam mempersiapkan dokumen 8 standar adalah sebesar $71,25673 \%$ sehingga masuk dalam kategori cukup siap karena pengelola PKBM rata-rata sudah memiliki dokumen yang dibutuhkan untuk proses pendaftaran akreditasi.

Kesiapan pengelola PKBM di Kabupaten Rejang Lebong dalam mempersiapkan unjuk kerja/Pelaksanaan kegiatan adalah sebesar 62,32039\% sehingga masuk dalam kategori kurang siap karena data yang ditemukan kurang sesuai dengan dokumen 8 standar.

\section{REFERENSI}

BAN PAUD DAN PNF. 2019. Kebijakan Dan Mekanisme Akreditasi Pendidikan Anak Usia Dini dan Pendidikan Nonformal.

Dewi,I,P. 2017. Mutu Lembaga Kursus dan Pelatihan Dalam Mengikuti Kesiapan Akreditasi Lembaga (Tesis). Bandung : Universitas Pendidikan Indonesia

Riduan. 2004. Belajar Mudah Penelitian untuk Guru DAN Peneliti Pemula. Bandung : Alfabeta
Sudjana, D. 2002. Metoda Statistika. Bandung : PT TARSITO

Slameto, 2010, Belajar dan Faktor-Faktor Yang Mempengaruhinya. Rineka Cipta

Sugiyono. 2013. Metode Penelitian Kombinasi (Mixed Methods) Alfabeta. Bandung

Sugiyono, 2015, Metode Penelitian Kuantitatif dan Kualitatif. Alfabeta. Bandung 